\title{
Literature, Resistance, and Visibility: "Draupadi," by Mahasweta Devi, in Translation
}

\section{Cielo G. Festino and Liliam Cristina Marins}

\section{(2) OpenEdition \\ 1 Journals}

Electronic version

URL: https://journals.openedition.org/ces/7568

DOI: $10.4000 /$ ces.7568

ISSN: 2534-6695

Publisher

SEPC (Société d'études des pays du Commonwealth)

\section{Electronic reference}

Cielo G. Festino and Liliam Cristina Marins, "Literature, Resistance, and Visibility: "Draupadi," by Mahasweta Devi, in Translation", Commonwealth Essays and Studies [Online], 43.2 | 2021, Online since 23 July 2021, connection on 02 February 2022. URL: http://journals.openedition.org/ces/7568 ; DOI: https://doi.org/10.4000/ces.7568

This text was automatically generated on 2 February 2022.

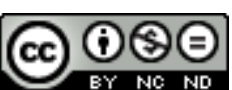

Commonwealth Essays and Studies is licensed under a Licence Creative Commons Attribution - Pas d'Utilisation Commerciale - Pas de Modification 4.0 International. 


\title{
Literature, Resistance, and Visibility: "Draupadi," by Mahasweta Devi, in Translation
}

\author{
Cielo G. Festino and Liliam Cristina Marins
}

1 The term "resistance" signifies a whole political and ideological way of thinking or fighting against any form of attack, violence, and repression suffered by a person, a minority group, or a people. Living in unfavorable social situations, the only form of resistance the oppressed usually find is through the use of their language and the circulation of their oral and written literature across local boundaries. Translation plays, for all practical purposes, an important role in making these literary texts and collective stories survive beyond their local space and time. This seems to be the case of the short story "Draupadi" by Mahasweta Devi, which went from an epic to a narrative written in Bengali and then to its translation into English by Gayatri Spivak.

2 If there is no possibility of representing every single particularity which contributes to the notion of universality, it is nonetheless necessary to review the traditionally inherited cultural knowledge we receive through certain social institutions and reproduce, in a never-ending cycle, attitudes toward what represents prestige literature. This reproduction many times excludes different identities already ignored and prohibited in other historical moments. However, according to Santiago CastroGomes (2005), this is a great opportunity for the invisible to become visible once the world faces a moment of crisis in modern thinking.

One way of valuing invisible thinking and knowledge, the different cognitive and linguistic experiences and the varied symbolic universes which we find in and through language, culture, and literature, is via intercultural translation (Sousa Santos 2007). In this process of (trans)formation, the others' differences are no longer limited to geographical borders, as literary works permit the expression of an emancipating way of thinking which translation then spreads beyond national borders. Devi's work, for example, is one of the most translated into English, and it was one of these translations which was responsible for giving her international exposure. 
4 This consolidation of a critical and transformative posture involves approaching translation in its political dimension. According to Esteves $(2014,255)$, the political dimension of translation acts as a sine qua non condition for addressing different cultures, because it is, to a great extent, dependent on political aspects. This is the reason why translations, in general, may function on the one hand as instruments of imperialism, whenever they are oriented by hegemonic power relations, and, on the other hand, as instruments of political intervention, every time they question these established relations and reinforce silenced and invisible identities. In India, a multilingual and plural country, readers are not necessarily familiar with all their different literary traditions; translation works then to strengthen the relationship between different communities and makes the invisible, visible, even inside the nation itself.

5 If translation is language in use, and language is always "crossed by political and ideological connotations" (Rajagopalan 2007, 19), ${ }^{1}$ translation becomes a powerful weapon for transforming social reality, especially for motivating empowerment, social representation, and critical citizenship. When doing so, language and translation call attention to what has often been covered and silenced for a long period of time because it did not correspond to the interests of the privileged classes. For that reason, this paper aims at analyzing how resistance is represented in literary and intercultural translation. In this regard, we take into consideration ideological perspectives in language use, narrative styles, and translation strategies to critically analyze the story "Draupadi" by Mahasweta Devi, as well as its translation into English by Gayatri Spivak.

\section{Translation and political intervention}

6 Translation, as a social practice materialized in and through language, is inevitably at the core of political and ideological crossings. Far beyond being a simple transposition of meaning from one language to another, translation is a place situated among different spaces, cultures and periods of time, "in which voices, wishes, and denunciation may appear subtly or more explicitly, but are never absent" (Esteves 2014). This statement leads the discussion to the more complex dimension of approaching translation as an act by individuals who deal with undoubtedly different languages, cultures, and symbolic universes and determined by politics.

7 Taking into account that working with language is necessarily "a political act, with all the ethical responsibility it involves" (Rajagopalan 2007, 16), ${ }^{2}$ it is through the use of language that "claims and political aspirations are guaranteed." ${ }^{3}$ Hence, as with any other political act, language is also guided by different ethical positions.

8 In Translation Studies, the importance of discussing the meaning of the -s added to the singular word "ethic" has been critically pointed out by Esteves (2014) and it illustrates how contexts are never associated with universal values. This unfolds a long-standing debate in translation regarding the existence of a more correct or better translation, i.e. correct according to whose ethics? Better to whom? Different situations involving several "translation scandals" (1996) were and still are in the spotlight, usually exposing situations in which a so-called incompetent translator has broken the law of fidelity to the original text. The image of translators-traitors is, then, constantly reinforced by this reference to a crime committed against the source text. However, if 
translation is a type of political and social praxis, there is no possibility of being loyal to anything. Treason is, under these circumstances, inevitable and, why not, desirable.

Translating is a process involving the production of meaning and is not exempt from the influences of its locus of enunciation, and this explains why there is no possibility of demanding neutrality in such human activity. In agreement with Sobral $(2008,34)$, our

enunciation is formed out of the accumulation of our experiences, social relations, and positions we occupy in society during our lifetime, including the constitutive presence of others. The formation of subjectivity of those others also depends on the accumulation of experiences, social relations maintained in life, and the mutable positions they occupy in a certain collectivity. ${ }^{4}$

The report of the American anthropologist Laura Bohannan (Esteves, 2008) is an example of how our interpretations are influenced by the way we interact with society and how we cannot avoid the effect of such interactions. As an example of an imperialist and colonized attitude, she took Hamlet, by Shakespeare, to a Nigerian community, trying to "translate" the play to the "wild" members of the non-literate community. However, during this process, she realized the community's meaningmaking of the play was totally "localized" and different from hers, as her interpretation was filtered through her white, Western, and hegemonic lens.

When she tried to attach the "true and absolute meaning" of the Shakespearean story the Western, academic, graphocentric meaning - to this community, she firmly believed its members would accept and agree with her interpretation. Nevertheless, while she was sharing the story with its members, the audience constantly interfered with her narrative in an attempt to express their resistance to what she saw as its true meaning. By doubting the anthropologist's interpretations, the members were actually validating their knowledge, space, culture, oral tradition, and epistemology in opposition to the outsider's. Their attitude illustrates the resistance of the colonized to the culture of the oppressor as well as the affirmation of their own native and oral tradition. As reported by Esteves $(2014,267)$, the oppressed need to choose between the culture of the oppressor in contrast with their native culture and oral tradition, which lacks the "Western literary capital."

11 Thus, translation may be used either as an instrument to maintain imperialism and hegemonic power relations, reinforcing silenced and negatively pre-conceived identities, or as a tool for political intervention. In both cases, translation becomes a "powerful political weapon, and the difference between the mentioned strategies is whether they are operated by the dominator or by the dominated to counterattack" (Esteves 2014, 269). ${ }^{6}$

12 In situations of colonization, the oppressor usurps properties, silences voices, and imposes his presence on the colonized people. Translation, in such cases, helps the dominator to transform the incomprehensible speech of the colonized into an intelligible discourse (Rajagopalan 1998, 1). These people only exist, according to Rajagopalan, when their discourse is translated into the prestigious language spoken by the colonizer. On the other hand, as an instrument of resistance and political intervention, translation challenges stereotypes, overcomes prejudice, reveals the colonizer's ideological interest and meets demands of the colonized: "Translation activity - the same one that validated the process of colonization - becomes, in the 
hands of colonized, the only means of resistance and, at the same time, the most powerful weapon for reaching their objectives" (Rajagopalan, 1998, 1). ${ }^{7}$

When translation attains this goal, increasing the visibility of different communities, narratives, and ways of living, it reflects the ambitious project of decoloniality. Mignolo held that decolonial thinking is indispensable in post-modernity to bring together "lost genealogies and present 'other' economic, political, social and subjective modalities" $(2007,44){ }^{8}$

14 As a protagonist in this decolonial project, translation can articulate differences and promote "atonement" (Esteves 2014, 268) ${ }^{9}$ for the acts of violence, suffocation, erasure, and indifference many people and subjects have been submitted to throughout history. Unlike situations in which translating Indian literary texts to English was part of the colonization process carried out by the British, in the next section, we present translation as a movement of resistance, empowerment, and intervention in an attempt to make Indian literature written by women visible. Not only are they made visible beyond their linguistic, cultural, symbolic, and geographic boundaries; they are validated inside their own community and country.

If still today translating Indian literary texts into English is considered by many as a legacy of the British colonial presence on the subcontinent, in the next section we analyze the short story "Draupadi" by Mahasweta Devi, as well as its translation into English by the internationally-known Indian critic, Gayatri Spivak, as an act of resistance and empowerment in an attempt to make not only Indian literature written by women known beyond its linguistic and cultural borders, but also the condition of the so-called Tribals, one of the marginalized Indian communities, as portrayed by Devi in her narrative.

\section{"Draupadi" by Mahasweta Devi: rewriting a feminine epic character}

16 In her discussion of Indian literature, Orsini (qtd. in Ciocca and Srivastava 2017, 7) points out that Indian readers and editors are not necessarily familiar with the different literary traditions of this multilingual and plural culture. This is why, in this context, translation is of great importance, because it contributes to strengthening the relationship between the various literary traditions in different languages. So much so that, as G.N. Devy observes, India is a culture with a translated consciousness, since the very foundations of modern Indian literatures are established through acts of translation $(1997,401)$. In order to neutralize power relations intrinsic to translation, not only "vertical translations," that is, translations of narratives from local languages into English, are encouraged, but also "horizontal translations," that is, among the vernacular languages. This latter form of translation is of great importance to maintain a good relationship between all Indian literary traditions (Ciocca and Srivastava 2017, 9). Along the same lines, Indra Nath Choudhuri points out that in India there is "unity of literary expression despite linguistic varieties" $(1997,440)$. What actually acts as a link, among all these languages, argues the author, is not the imposition of a single language like English or Hindi, or favouring some languages to the detriment of others that are reduced to the condition of dialects; the translation of works from one 
language into another actually contributes to encouraging "an elaborate pattern of inter-regional, inter-ethnic communication" (440).

Regarding the status of English in India, as it is well known, it is one of India's official languages, together with Hindi. Though English is associated with colonialism and the elites, it is a vehicular language that circulates among Indians of different castes. As it has been vernacularized, it is also considered as one of the local languages. Translations into English can therefore be considered as strategies of political activism, in particular by oppressed groups, as they act as a counter-hegemonic discourse and even allow audiences beyond the national borders to become familiar with the literature of a people, written in a vernacular language and of restricted circulation (Ciocca and Srivastava 2017, 11-13).

One of the best-known translations of an Indian literary work into English is that of the Bengali writer, Mahasweta Devi's (1926-2016) short story, "Draupadi," by Gayatri Chakravorty Spivak, also from Bengal. Both Devi's writing of engaged literature and Spivak's translation of these works into English become instruments of political intervention (Esteves, 2014) in the sense that they problematize preconceived cultural identities. Devi is one of the Indian writers most translated into local as well as European languages. She was an anthropologist, journalist, and author of a vast literary oeuvre that includes novels, plays and short stories. She belonged to a family of intellectuals. Like her father and mother, who were writers and political activists, Devi fought for the rights of the so-called Tribals of India, in particular, the women of the Santal community, an ethnic group which lives in West Bengal, Jharkhand, Assam, Bihar and Odisha as well as Bangladesh. These experiences became literary works that have earned Devi several awards at a national and international level.

Tribals consider themselves as the first inhabitants of the Indian subcontinent - they are also called "Adivasi" which means "first settlers" - before being displaced by the arrival of the Aryans and becoming foreigners in their own territory, living today on its periphery and being constantly discriminated against (Pereira 2009, 1). ${ }^{10}$ India has the largest tribal population in the world, approximately 67.6 million people, eight percent of the national population. According to Minoli Salgado, Tribals do not always have access to basic rights, such as land tenure, health and education $(2008,150)$. In turn, as Devi emphasizes in each of her literary works, the tribal category is not monolithic or permanent. Each tribal community, spread across the Indian territory, has its own characteristics, as the name of the group, its village and its leaders attest. At the same time, Devi makes a point of showing in her literature that Tribals are Indian like the rest of the inhabitants of the subcontinent and, therefore, must be included in the mainstream community. If she denounces these ills in each of her literary works, written in Bengali, its translation into English makes them known all over India as well as abroad.

20 If Devi's work is one of the most translated into English, it was Spivak who gave her international exposure. However, as the Indian critic Brinda Bose points out, Spivak is aware of the problems inherent in the representation, made through translation, of a Third World writer, by a recognized critic in the First World, though from the same country $(2008,71)$. The book Imaginary Maps, in which Spivak's translation of "Draupadi" appears, entered the market with her name. Mahasweta Devi, however, has expressed her support of Spivak for contributing to the dissemination and reading of 
her literature, and also for the interest that Spivak has shown in relation to the communities about which Devi writes (2008, 222-23).

Spivak's translation is preceded by a critical reflection on the act of translation, "Translator's Foreword," which has caused many controversies (Bose 2008; Salgado 2008). On the one hand, Spivak makes it clear that both her choice of the literary text to translate and her translation strategies are determined by politics (Esteves 2014). On the other hand, as noted by Bose (2008, 72), if Spivak's translation contributed to Devi's work being discussed beyond the borders of Bengal, her theoretical position in the "Foreword" ends up guiding the reading of the story. In this Foreword, she shares with the reader the difficulties she had in becoming familiar with the language spoken by the Tribals and justifies her choice of "Standard English" at the same time that she ironizes about the definition of what might be considered "standard" as observed in the reflection below:

I have had the usual "translator's problems" only with the peculiar Bengali spoken by the tribals [...]. It would have been embarrassing to have used some version of the language of D.H. Lawrence's "common people" or Faulkner's blacks. Again, the specificity is micrological. I have used "straight English," whatever that may be. $(1981,395)$

Spivak's desire to remain loyal to Devi's writing rather than adapt "Draupadi" to the foreign audience is shown by her translation strategies: to purposefully italicize words used in English in the original text in Bengali - a fact that already shows, as stated above, the vernacularization and circulation of English in India - or not to translate into English parts of the original text written in the language of the Santals - thus giving visibility to a vernacular language. More than simply illustrating examples of untranslatability, these strategies reveal the desire to leave the marks of the translated Other in the text, causing a de-automaticization of the process of reading and thus becoming an example of translation as political intervention (Esteves 2014). Reading a text written in English but coming across terms in the language of the Santals disturbs the flow of reading and draws attention to the presence of the mother tongue which is other than the English language. Likewise, Spivak's translation has ethical value because the choice of the author, Devi, and the short story, "Draupadi," show that, for Spivak, literature is an ideological act and translation, an act of resistance, since Devi's work is political.

The story recounts the tragic adventure of a twenty-seven-year-old political activist, Dopdi Mejhen, married to another political activist, Dulna Mahji, both belonging to the Santal community. The narrative is divided into two main parts. In the first one, in which Dopdi and Dulna together with their fellow rebels roam the countryside causing havoc in order to defend the rights of their people, the tone is one of romance, ironizing the blindness of India's Special Forces, unable to translate the signs of their own culture, and idealizing the figure of the brave Santals. In the second, when Dopdi actually gets caught, the tone becomes dramatic, as she becomes a tragic heroine. The Indian Forces, however, remain as blind as ever as Dodpi continues to be impossible for them to understand. The style of the short story is highly functional as it articulates the political content of the narrative through the parody of different forms of official discourse: want ads, police talk, police dossier, Indian Constitution, Army Handbook, official press. If the aim of these different textual genres is to translate rebel Dopdi and her comrades into official language, thus simultaneously renaming and silencing her, Devi's aim in the story is to retranslate these forms of discourse so that the Tribals, in 
this case the Santal community, will be perceived in their tragic fight against the establishment:

Name Dopdi Mejhen, age twenty-seven, husband Dulna Majhi (de-ceased), domicile Cherakhan, Bankrajharh, information whether dead or alive and/or assistance in arrest, one hundred rupees... An exchange between two liveried uniforms.

FIRST LIVERY: What's this, a tribal called Dopdi? The list of names I brought has nothing like it! How can anyone have an unlisted name?

SECOND: Draupadi Mejhen. Born the year her mother threshed rice at Surja Sahu (killed)'s at Bakuli. Surja Sahu's wife gave her the name.

FIRST: These officers like nothing better than to write as much as they can in English. What's all this stuff about her?

SECOND: Most notorious female. (Devi 1981, 392)

The reader's first encounter with the main character is thus through a police leaflet which promises a reward of one hundred rupees to anyone who finds Dopdi alive or dead. Although illiterate and uneducated, Dopdi is an intelligent and brave woman who fights for the rights of her community and, together with her husband, dares to lead an armed uprising against the state. Then, through the first of a series of linguistic, cultural and literary translations through which Devi tells the story of her ill-fated heroine, Dopdi is presented to the reader through the conversation of two police officers purposely called by Devi Liveried One and Liveried Two, thus mocking their surprise that Dopdi, a Tribal sought by the police, was not on the list of most wanted criminals, because her name was not typical of her community. "Dopdi" is the rewriting of the Sanskrit name "Draupadi." This change from Draupadi to Dopdi can be explained in two ways as Spivak points out: the difficulty of a Tribal in pronouncing a word in Sanskrit, the Indian language of learning, or its appropriation, and consequent translation, by the Santals to their own language, which few in Bengal know $(1981,387)$. The irony lies in the fact that not only do Tribals resist Aryan culture, as can be seen in the tale, but Sanskrit, the language of Aryan culture, is forbidden to them, just as it is to low-caste people and Tribals. That name had been given to Dopdi by the wife of the farm owner on whose property her mother had worked during a harvest. The fact is symbolic, since, although the farmer's attitude is benevolent, it reveals the power relations among members of different castes, class and ethnic groups within the same community. If the farmer has the power to name the Other, adapting the name to the language of the Santals can be understood as a form of resistance. Moreover, it is the husband of this woman that Dopdi and Dulna end up murdering during a peasant uprising.

As mentioned above, it is through the police dossier, another official discourse genre, that both we, readers, and the police come to know that Dopdi, like her husband, Dulna Majhi, who is already dead, were itinerant workers, employed in the harvests, until they participated in Operation Baluki in 1971, when, during a drought, they occupied wells that could only be used by people of the highest castes. They also killed a farmer and his son, and later refused to hand over the companions involved in the operation. Today, Dopdi, a widow, has gone underground in the forest:

Dossier: Dulna and Dopdi worked at harvests, rotating between Bir-bhum, Burdwan, Murshidabad, and Bankura. In 1971, in the famous Operation Bakuli, when three villages were cordoned off and machine gunned, they too lay on the ground, faking death. In fact, they were the main culprits. Murdering Surja Sahu and his son, occupying upper-caste wells and tubewells during the drought, not surrendering those three young men to the police. In all this they were the chief instigators. In the morning, at the time of the body count, the couple could not be found. The 
blood-sugar level of Captain Arjan Singh, the architect of Bakuli, rose at once and proved yet again that diabetes can be a result of anxiety and depression. Diabetes has twelve husbands - among them anxiety. (Devi 1981, 392) mernment's lack of knowledge not only of the Santals but of Tribals. Rather than assuming a dramatic tone, she ironically imitates official discourse to show their ignorance and indifference to Tribals as well as their disregard of the Indian Constitution, the only official discourse that should actually be heeded. First, by showing that Dopdi dodges the Special Forces because for them, all Tribals are the same and, if they are unable to understand the Santals, the latter are very familiar with the establishment's way of acting. Rather than succumbing to their "reason" they know how not to fall prey to it:

By the Indian Constitution, all human beings, regardless of caste or creed, are sacred. Still, accidents like this do happen. Two sorts of reasons: (1), the underground couple's skill in self-concealment; (2), not merely the Santals but all tribals of the Austro-Asiatic Munda tribes appear the same to the Special Forces. (Devi 1981, 392-93)

The other official discourse which guides the Special Forces, rather than the Indian Constitution, is the Army Handbook (393), according to which the sacred duty of any soldier is to destroy guerrilla warfare. Then, Sananayak's inability to understand 
Tribals becomes evident in an actual act of linguistic and cultural translation. He is intrigued by the last words, "Ma-Ho" (395), spoken by Dopdi's husband at the time of his death at the hands of the armed forces. In order to discover the meaning of the words, the experts in Tribal communities arrive from Calcutta with important dictionaries by foreign authors, perhaps Orientalists. Through this twist in the plot, Devi marks the unbridgeable distance that exists in India between mainstream culture and not only Tribals but also low caste people and Dalits, showing that, like a poor translator, Sananayak's reading of "The Deputy," rather than leading him to challenge stereotypes, has only led him to reaffirm his own prejudices. This is due to the fact that though India was liberated from the English in 1947, members of its elites still adhere to colonial ways of thinking in their treatment of the Indian downtrodden. At another level, both the story and translation are examples of the need to decolonize the Indian mind in order to purge Indian society of any remnants of the colonial experience.

The person who actually reveals the meaning of the words, however, is the man who supplies the police camp with water. Amid chuckles, he explains to the chief of police that these were the words used by the Santals of Maldah when they fought during King Gandhi's time. With great irony, the man asks if they had brought someone from Maldah to help them with the translation:

What does "Ma-ho" mean? Is this a violent slogan in the tribal language? Even after much thought, the Department of Defense could not be sure. Two tribal-specialist types are flown in from Calcutta, and they sweat over the dictionaries put together by worthies such as Hoffmann-Jeffer and Golden-Palmer. Finally the omniscient Senanayak summons Chamru, the water carrier of the camp. He giggles when he sees the two specialists, scratches his ear with his "bidi," and says, The Santals of Maldah did say that when they began fighting at the time of King Gandhi! It's a battle cry. Who said "Ma-ho" here? Did someone come from Maldah? (Devi 1981, 395)

Devi invests Chamru's answer with a decolonial purpose. Through a true epistemic fight that "calls for equality among forms of knowledge" (Vergès 2020, 39), his simple but profoundly wise answer equals or even surpasses the knowledge of the learned scholars who might know the Santals' culture in theory but not in the practice.

In another act of translation, Devi presents her character Dodpi as a racialized recreation of the Draupadi, the character from the Indian epic Mahabharata. Dopdi is what Vergès $(2020,36)$ defines as an autochthonous woman whose struggle is a continuation of that of her ancestors, who were reduced almost to slavery, during colonial times. If women like Draupadi were doubly colonized by patriarchal society and the colonizer, Dopdi is triply colonized, considering that to these two layers of submission a third one should be added, as she is racialized by the upper castes and classes. In her recreation of Dopdi, Devi establishes a counterpoint between the two characters. The Draupadi of the epic is one of the heroines of Indian culture and literature, like the Sita of Ramayana. Unlike Dopdi, Draupadi is of high caste and is one of the few examples of polyandry in India, since she is shared by the five brothers of the Pandava family. If, on the other hand, Dopdi has a monogamous marriage, the police officers rape her repeatedly after her arrest, which, paradoxically, contributes to bringing her closer to the figure of Draupadi. Both women are involved in violent situations caused by men. In the case of Draupadi, her oldest husband, whose weak point was gambling, bet her in a game of dice and was on the verge of losing her. As the Vedas do not recognize polyandry, the chief of the Kaurava family, rivals of the Pandava family, treats Draupadi as a prostitute and thinks it is not unworthy to undress 
her in public. Draupadi makes an appeal to the God Krishna and, each time King Kaurava pulls on her sari, the God covers her with an infinitely long fabric.

Devi rewrites this scene from the Mahabharata not only when she changes the name from Draupadi to Dopdi, but also when she presents Dopdi as a woman despised by mainstream Indian culture, yet treated with respect by the men in her community. If Draupadi is a victim of her husband's addiction and the Kauravas' crudeness, Dopdi fights side by side with her husband. Although both women are heroic, Dopdi's way of resisting, as a result of belonging to another community and another historical moment, is different from Draupadi's. When she is raped, she lets her aggressor undress her and, significantly, does not appeal to the Gods for help. After being raped repeatedly by the police officers, for endless days and nights, she rejects the water offered to her and, instead of covering herself, in a defiant attitude, tears her clothes with her teeth and faces the police chief, spitting blood on his immaculate white shirt and making a point of showing her naked body with the argument that there was no reason for modesty when all the police officers knew her intimately:

... what's the use of clothes? You can strip me, but how can you clothe me again? Are you a man? She looks around and chooses the front of Senanayak's white bushshirt to spit the bloody gob at and says: There isn't a man here that I should be ashamed. I will not let you put my cloth on me. What more can you do? Come on, counter me, come on, counter me......... Draupadi pushes Senanayak with her two mangled breasts and for the first time Senanayak is afraid to stand before an unarmed target, terribly afraid. (Devi 1981, 402)

Dopdi is not weakened or embarrassed by the rape as other women in similar situations might be. Rather, like the jubilant song she sang together with her husband, "in a savage tongue, in-comprehensible even to the Santals" (393), she establishes a new threshold of resistance and decolonization that sets her apart even from the women of her own community. Her attitude is as difficult for the baffled Chief of Police to translate as the words of her song by Spivak. Although her body has been ravaged, her inner strength remains intact. Dopdi's refusal to cover her naked and bloody body is an affront to the attacker: she insists that the police chief see how his order to rape her had been carried out. It is through this form of protest and resistance, unforeseen and different, that Dopdi rejects the values of dominant and patriarchal society, which leaves the aggressor confused and speechless, and transforms her into a superior being. She becomes a sign that the police officer is unable to translate. The rewriting of the Indian epic through the recreation of Draupadi as Dopdi can be understood as Mahasweta Devi's tribute to Tribal women. In turn, Spivak's translation of such a unique narrative is coupled with Devi's desire of atonement for the Santals. Both the original short story and the translated version contribute to uncovering an unfair and cruel social reality. In this sense, translation, as well as engaged literature, becomes a powerful weapon for transforming social reality (Rajagopalan 2007).

The theme and style of the story reveal that Devi's writing goes beyond a linguistic and aesthetic act to become a political act against forms of gender and racial oppression, in this case, of a marginalized community such as the Tribals in India. In turn, Spivak's translation is also an act of resistance when she makes it clear that the story of suffering of a community considered as a minority should be spread throughout India and internationally in order to serve as an example to the many women subjugated by patriarchal society, as well as to other marginalized communities. Author and translator, together, make the literary work and its translation an alternative discourse 
that recreates the identity of the tribal subordinate while problematizing and deconstructing the Indian nationalist discourse.

\section{Final Words}

31 As we have tried to show in this article, literature and translation can be understood as spaces for reflection that aim to problematize the official discourse about minority groups, and to consider alternative discursive versions so that silenced communities can be heard. In this context, the act of translation, "intimate" and "hospitable" (Almeida 2011, 9), allows us to approach the Other, to mirror ourselves in their conflicts and, consequently, to reflect on the problems of the community in which we are inserted.

Both literature and translation make this process possible because both have the power to relate different cultures; in the case of literature, through metaphors of great affective value, and translation, through the translation act understood as "an endless act of weaving" (Almeida 2011, 9) the stories of one culture with those of another. Thus, local stories become known through other languages and in other cultures. As also observed by Almeida $(2011,10)$, "starting from the consideration that language is a process of construction of meaning, a means through which we make sense of things and ourselves and, thus, produce our identities, translation allows us to make contact with a language that belongs to several 'Others'."

When these narratives of these "several others," in which we mirror ourselves, are consistently articulated in successive literary narratives and, in turn, translated, they cease to be an aesthetic exercise and become a social issue. It is at this moment that the theories proposed by literature and translation become a practice that can contribute to changing the life of the Other as well as our own.

\section{BIBLIOGRAPHY}

ALMEIDA, Sandra R.G. 2011. "Mediações contemporâneas: tradução cultural e literatura comparada." Gragoatá 16, no. 31: 77-96.

BOITO, Fernanda, and Liliam MARINS. 2017. "Relações de 'poder' e legendagem: revisitando o conceito de 'poder' como substantivo autoritário para verbo de ação no processo tradutório." Tradterm 30: 87-101.

BOSE, Brinda. 2008. “The Intimacy of Translation: The Case of Mahasweta Devi's 'Draupadi'." In Mahasweta Devi. An Anthology of Recent Criticism, edited by Nivedita Sen and Nikhil Yadav, 71-85. New Delhi: Pencraft International.

CASTRO-GÓMEZ, Santiago, and Ramon GROSFOGUEL. 2005. "Giro decolonial, teoría crítica y pensamiento heterárquico." In El giro decolonial: reflexiones para uma diversidad epistêmica más allá del capitalismo global, edited by Santigao Castro-Gómez and Ramón Grosfoguel, 63-78. Bogotá: 
Siglo del Hombre. https://archive.org/stream/perspectivas_decoloniales_musica_sonido/ grosfoguelcastrogomez_djvu.txt.

CHOUDHURI, Indra Nath. 1997. "The Plurality of Languages and Literatures in Translation: The Post-colonial Context." Meta: Translators' Journal, 42, no. 2: 439-43.

CIOCCA, Rossella, and Neelam SRIVASTAVA, eds. 2017. Indian Literature and the World. Multilingualism, Translation and the Public Sphere. London: Palgrave Macmillan.

DEVI, Mahasweta. 1981. "Draupadi." Translated by Gayatri Chakravorty Spivak. Critical Inquiry "Writing and Sexual Difference" 8, no. 2, (Winter): 381-402.

DEVI, Mahasweta. 2008. "Speaking with Mahasweta Devi: Mahasweta Devi interviewed by Gabrielle Collu." In An Anthology of Recent Criticism, edited by Nivedita Sen and Nikhil Yadav, 22135. New Delhi: Pencraft International.

DEVY, Ganesh N. 1997. "Literary History and Translation: An Indian View.” In Meta 42, no. 2: 395405. https://doi.org/10.7202/002560ar.

ESTEVES, Lenita Maria Rimoli, and Francis Henrik AUBERT. 2008. "Shakespeare in the bush, história e tradução." Tradução e comunicação17: 13568.

ESTEVES, Lenita Maria Rimoli. 2014. Atos de tradução: éticas, intervenções, mediações. São Paulo: Humanitas.

MIGNOLO, Walter. 2005. "El pensamiento decolonial: desprendimiento y apertura. Um manifiesto." In El giro decolonial: reflexiones para uma diversidad epistêmica más allá del capitalismo global, edited by Santigao Castro-Gómez and Ramón Grosfoguel. Bogotá: Siglo del Hombre. https://archive.org/ stream/perspectivas_decoloniales_musica_sonido/grosfoguelcastrogomez_djvu.txt.

PEREIRA, Claudia. 2009. Casta, Tribo e Conversão. Os Gauddes de Goa. PhD diss, Lisbon, ISCTE-IUL.

RAJAGOPALAN, Kanavilil. 2000. "Pós-modernidade a tradução como subversão." Anais do VII Encontro Nacional 1 Encontro Internacional de Tradutores, São Paulo. http://www.novomilenio.inf.br/idioma/ 19980911.htm.

RAJAGOPALAN, Kanavilil. 2007. "Por uma linguística crítica." Línguas \& Letras. Unioeste 8, no. 14: 1320.

SALGADO, Minoli. 2008. "Tribal Stories, Scribal Worlds.” In Mahasweta Devi. An Anthology of Recent Criticism, edited by Nivedita Sen and Nikhil Yadav, 148-65. New Delhi: Pencraft International. SANTOS, Boaventura de Sousa. 2007. “Para além do pensamento abissal: das linhas globais a uma ecologia de saberes.” Novos estud. - CEBRAP [online], no.79: 71-94.

SOBRAL, Adail. 2008. Dizer o 'mesmo' a outros: ensaios sobre tradução: ensaios sobre tradução. São Paulo: SBS.

SPIVAK, Gayatri Chakravorty. 1981. “'Draupadi' by Mahasweta Devi.” Critical Inquiry 8, no. 2, "Writing and Sexual Difference" (Winter): 381-402.

VENUTI, Lawrence. 1996. “O escândalo da tradução.” Tradterm 3: 99-122.

VERGÈs, Françoise. 2020. Um Feminismo Decolonial. Translated by Jamille Pinheiro Dias and Raquel Camargo. São Paulo: Ubueditora. Originally published as Un féminisme décolonial (Paris: La Fabrique, 2019). 


\section{NOTES}

1. "atravessada pelas conotações político-ideológicas." (This, and all subsequent translations from Portuguese are ours.)

2. "agir politicamente, com toda a responsabilidade ética que isso acarreta."

3. "se faz valer suas reivindicações e suas aspirações políticas."

4. "maneira de enunciar advém da soma total de nossas vivências, de nossas relações sociais, ao longo da vida, e das posições sociais que chegamos a ocupar numa dada coletividade, o que supõe a presença constitutiva do outro. Porque o outro também vai se formando como sujeito na coletividade, tem sua soma total de vivências, das relações sociais que mantém ao longo da vida, das posições mutáveis que ocupa numa dada coletividade ao longo da história, tanto de sua vida como dessa coletividade."

5. "capital literário ocidental."

6. "uma poderosa arma de intervenção política, seja para dominar ou para contra-atacar o poder dominador."

7. "a atividade tradutória - a mesma que selou o processo de colonização - acaba se tornando, nas mãos dos colonizados, o único meio de resistência e, ao mesmo tempo, a arma mais poderosa para alcançar seus objetivos."

8. "genealogías desperdigadas por el planeta y ofrezca modalidades económicas, políticas, sociales y subjetivas 'otras'."

9. "reparações."

10. While Adivasis or Scheduled Tribes are ethnic minorities across the sub-continent, Dalits, formerly called "Untouchables" belong to the lowest rung of the caste system. What both groups have in common is that they are oppressed and marginalized.

\section{ABSTRACTS}

This article aims to analyze how resistance is articulated in literary and intercultural translations. In this regard, we take into consideration ideological perspectives in language use, narrative styles, and translation strategies as discussed by Esteves (2014), Sobral (2008) and Almeida (2011) to analyze the story "Draupadi," by Mahasweta Devi, as well as its translation into English by Gayatri Spivak (1981).

\section{INDEX}

Keywords: translation, Tribals, resistance, Mahasweta Devi

\section{AUTHORS \\ CIELO G. FESTINO}

Universidade Paulista, São Paulo 
Cielo G. Festino teaches English at Universidade Paulista, São Paulo, Brazil. She is a member of the thematic project "Thinking Goa: A Singular Archive in Portuguese" (2015-2019 / USP-

FAPESP). She recently co-edited A House of Many Mansions. Goan Literature in Portuguese. An Anthology of Original Essays, Short Stories and Poems (Under the Peepal Tree, 2017), and an issue of the Interdisciplinary Journal of Portuguese Diaspora Studies entitled "Goans on the Move" (2018).

\section{LILIAM CRISTINA MARINS}

Universidade Estadual de Maringá

Liliam Cristina Marins teaches Literature and Translation at Universidade Estadual de Maringá, Paraná, Brazil. She is the coordinator of the project "Translation and multidisciplinarity: from Babel Tower to technological society" (2011-2022/ UEM) and the editorial director of Acta Scientiarum: Language and Culture. Together with Rosa Maria Olher, she recently edited the book From Babel Tower to Technological Society: Translation and Multidisciplinarity (Clube de autores, 2018). 